\title{
Corporate Income Taxation of Multinationals in a General Equilibrium Model
}

\author{
THOMAS EICHNER \\ MARCO RUNKEL
}

\section{CESIFO WORKING PAPER NO. 2320 \\ CATEGORY 1: PubliC FinANCE \\ JUNE 2008}

Presented at CESifo Area Conference on Public Sector ECONOMics, April 2008

\footnotetext{
An electronic version of the paper may be downloaded

- from the SSRN website:

www.SSRN.com

- from the RePEc website:

- from the CESifo website:

www.RePEc.org

www.CESifo-group.org/wp
} 


\title{
Corporate Income Taxation of Multinationals in a General Equilibrium Model
}

\begin{abstract}
This paper contributes to the discussion on Separate Accounting versus Formula Apportionment in the corporate income taxation of multinational enterprises (MNEs). The innovation of the analysis is that we consider a general equilibrium tax competition model with an endogenously determined world interest rate. Under the principle of Separate Accounting, it turns out that corporate tax rates may be inefficiently low or high, while under Formula Apportionment corporate tax rates are always inefficiently low. These results are true independent of whether the number of countries is small or large. They reverse the insights obtained by previous studies under the assumption of an exogenously given world interest rate.
\end{abstract}

JEL Code: H7, H73.

Keywords: corporate income tax, Separate Accounting, Formula Apportionment.

Thomas Eichner Department of Economics

University of Bielefeld

Universitätsstrasse 25

33615 Bielefeld

Germany

teichner@wiwi.uni-bielefeld.de
Marco Runkel

Faculty of Economics and Management University of Magdeburg

P.O. Box 4120

39016 Magdeburg

Germany

marco.runkel@ovgu.de

May 10, 2008

We would like to thank participants of the CESifo Area Conference on Public Sector Economics in Munich, Jay Wilson and Matthias Wrede for their helpful discussion. The usual disclaimer applies. 


\section{Introduction}

There are basically two alternative principles in the taxation of multinational enterprises (MNEs). The first principle is Separate Accounting. Under such a taxation system, corporate income of a MNE is taxed by the tax code of the country in which the MNE the income declares. The second principle is Formula Apportionment. This taxation system is mainly characterized by two properties. The tax bases of all subsidiaries of the MNE are first consolidated and then apportioned to the taxing countries according to a predetermined formula that usually reflects the MNE's property, sales and payroll shares in the respective countries. While Separate Accounting is in operation at the international level, some countries like the U.S., Canada, Germany and Switzerland apply Formula Apportionment at the national level.

The European Commission (2001) presented plans to reform the corporate income taxation of MNEs within the boarders of the European Union. The idea is to replace the current system of Separate Accounting by Formula Apportionment. In 2004 the European Commission set up the so-called Common Consolidated Corporate Tax Base Working Group in order to develop concepts for introducing a common European tax base. Such a common tax base definition is seen as a prerequisite for introducing Formula Apportionment. The European Council plans to decide on the introduction of Formula Apportionment during 2008. These activities in the European Union brought in its wake a heated discussion about the pros and cons of the two corporate taxation principles both among politicians and among economists.

Our paper contributes to this discussion. Using a tax competition model with a representative MNE and Leviathan governments, we investigate the efficiency properties of the two tax principles by identifying fiscal externalities caused by the countries' tax policy. The innovation of the paper is that it uses a general equilibrium model. Such an approach explicitly takes into account the world capital market where the interest rate is endogenously determined. The advantage of the general equilibrium framework is that it allows to consider large countries whose governments are aware of their effects on the world price of capital. And even for small countries, each of which takes the interest rate as given, aggregate policy changes of all countries have an impact on the interest rate when it is endogenously determined. Hence, a general equilibrium model like ours is more appropriate to investigate the principles of Separate Accounting and Formula Apportionment: Regardless of whether countries are large or small in the above sense, taxation under both systems will have effects on the interest rate which 
should be taken into account when evaluating the two principles in terms of efficiency.

This is particularly true as our analysis yields results that are detrimentally different from those obtained in previous studies under the assumption of a fixed world interest rate. Under Separate Accounting, it turns out that the cross country effect of one countries tax rate consists of a profit shifting externality and a tax base externality. The former states that a corporate tax rate increase in one country induces the MNE to shift more profit to other countries, thereby improving the tax base and tax revenue in other countries. This externality is positive. The tax base externality reflects the impact of one country's tax rate on the other countries' tax base and tax revenue via changes in the quantities and prices of production inputs. A tax rate increase in one country reduces capital demand in this country and raises investment in other countries through a fall in the world interest rate. As consequence, there is a positive effect on the tax base and tax revenue in other countries. But the increase in investment is accompanied by an increase in labor demand and wages which, in turn, reduces the tax base and tax revenue in the other countries. Overall the tax base externality may be positive or negative. Hence, the sign of the total cross country effect of corporate tax rates under Separate Accounting is ambiguous, leaving it open whether countries end up with inefficient over- or undertaxation.

Under Formula Apportionment, in contrast, corporate tax rates are unambiguously too low. With consolidation and apportionment the cross country effect of tax rates can be decomposed into a formula externality and a tax base externality. As the profit shifting externality under Separate Accounting, the formula externality is positive: If one country raises its tax rate the MNE reallocates capital and labor from this country to other countries. In doing so, it reduces its tax burden by lowering the share of the consolidated tax base assigned to the tax-increasing country and by increasing the share of the consolidated tax base assigned to the other countries. As consequence, the tax revenue in the other countries goes up. The tax base externality again reflects the impact of one country's tax rate on the other countries' tax base and tax revenue through changes in quantities and prices of production inputs. In contrast to Separate Accounting, however, it is now the consolidated tax base that determines tax revenue of the countries. Hence, the effects via investment and wages cancel out and do not influence the tax base. Only the reduction in the interest rate matters. It reduces capital cost and increases the consolidated tax base and tax revenue in the other countries. Hence, the tax base externality under Formula Apportionment is unambiguously positive and corporate tax rates will always fall short of their efficient levels. 
These results reverse the insights obtained by previous studies. There is by now a large number of studies investigating Separate Accounting versus Formula Apportionment. Examples are McLure (1980), Mintz and Smart (2004) and Nielsen et al. (2003). Our paper is closely related to Gordon and Wilson (1986), Eggert and Schjelderup (2003), Wellisch (2004), Sørensen (2004), Nielsen et al. (2006), Riedel and Runkel (2007), Pinto (2007), Pethig and Wagener (2008) and Eichner and Runkel (2008). But in contrast to our approach, all these papers use partial equilibrium models with a given world interest rate. Hence, the tax base externality under Separate Accounting is missing since the increase in one country's tax rate reduces only the MNE's capital and labor demand in this country, but neither the world interest rate nor the production inputs in other countries. For the same reason, the effects on the consolidated tax base via changes in the production inputs do not cancel out, so the sign of the tax base externality under Formula Apportionment becomes indeterminate. The basic insight of previous studies is therefore that the corporate tax rates under Separate Accounting are inefficiently low (due to the positive profit shifting externality), whereas they may be inefficiently low or high under Formula Apportionment (due to the indeterminate sign of the tax base externality). These insights are detrimentally different to those derived in our framework under the assumption of an endogenous world interest rate. We show that this difference in results prevails if we let the number of countries go to infinity and each country becomes small.

If we abstract from profit shifting, our analysis of the Separate Accounting principle is also related to the traditional literature on (capital) tax competition. For example, Wilson (1985, 1986) and Zodrow and Mieszkowski (1986) establish inefficiently low capital tax rates in a tax competition model with a large number of countries. This result has been extended to settings with a small number of countries by Crombrugghe and Tulkens (1990). Hoyt (1991) unifies both approaches and shows that the race to the bottom sharpens when the number of countries increases. The basic reason for undertaxation in these studies is a positive capital flight externality. If one country increases its tax rate, capital flows out of this country and thereby increases investment in other countries. This externality is similar to our tax base externality under Separate Accounting. In our framework, however, the tax base externality may be positive or negative. The reason for this difference is that the above authors model capital taxes as a (unit) wealth tax on capital, whereas we explicitly consider a tax on corporate income. Hence, in our model there may be a negative effect of one country's tax rate on the other countries' tax base working through changes in labor demand and wages. 
The paper is organized as follows. In Section 2, we introduce the basic assumptions of our model. Section 3 and 4 investigate the efficiency properties of corporate tax rates under Separate Accounting and Formula Apportionment, and Section 5 concludes.

\section{Basic Assumptions}

Consider an economy with $n \geq 2$ identical countries. We use $i, j, h=1, \ldots, n$ as country indices. There is a large number of MNEs operating a plant in each country. The MNEs are structurally the same, so we restrict attention to a representative MNE. In country $i$, the MNE produces a consumption good according to the production function $F\left(k_{i}, \ell_{i}\right)$ where $k_{i}$ is capital and $\ell_{i}$ is labor employed in the production of country $i$. The production function $F$ has the usual properties. It exhibits positive and decreasing marginal returns to capital and labor, i.e. $F_{k}, F_{\ell}>0$ and $F_{k k}, F_{\ell \ell}<0$. In addition, capital and labor are supposed to be complements in the sense that $F_{\ell k}>0$. As the previous literature on Separate Accounting versus Formula Apportionment, we consider the case of decreasing returns to scale with respect to capital and labor. This assumption implies that there is at least one fixed factor in production (say, entrepreneurial services) that generates economic rents. In the analysis of corporate income taxation, the existence of economics rents is a useful property since these rents represent the corporate income the governments try to tax.

The MNE may shift profit between its subsidiaries. This can be done, for example, by manipulating the subsidiaries' debt equity structure, distorting transfer prices of goods and services traded between the subsidiaries or distributing overhead cost between the subsidiaries. The specific shifting channel is immaterial for our purpose. We simply model the effect that profit shifting changes the tax bases of the subsidiaries. Formally, the variable $s_{i}$ denotes the change in the tax base of the subsidiary located in country $i$. If $s_{i}>0\left(s_{i}<0\right)$, then the tax base in country $i$ goes up (down) since the MNE shifts profit to (from) country $i$. The shifting variables satisfy

$$
\sum_{j} s_{j}=0 .
$$

This condition ensures that $s_{i}$ represents shifting from or to country $i$ and not a change in the overall profit of the MNE. Profit shifting comes at a concealment cost that reflects, for example, the expense for tax consultants and the MNE's risk of being detected by the tax authority illegally shifting income (e.g. Kant, 1998, Haufler and 
Schjelderup, 2000). The concealment cost is represented by the U-shaped function $C\left(s_{i}\right)$ with $C(0)=0, \operatorname{sign}\left\{C^{\prime}\left(s_{i}\right)\right\}=\operatorname{sign}\left\{s_{i}\right\}$ and $C^{\prime \prime}\left(s_{i}\right)>0$. Note that this modeling implicitly assumes that one euro shifting between two subsidiaries causes cost in both subsidiaries. This is a realistic assumption. For example, in their transfer pricing regulation many countries force MNEs to document their transactions. This documentation is required for each subsidiary, i.e. the subsidiary in country $i$ has to document the transaction even if the subsidiary in country $j$ has already documented it. All documentations are costly since they are usually done by different tax consultants. ${ }^{1}$

For each unit of capital the MNE has to pay the world interest rate $r$. The user cost of capital in country $i$ therefore amounts to $r k_{i}$. Payroll in country $i$ is $w_{i} \ell_{i}$, where $w_{i}$ stands for the local wage rate in country $i$. In order to define the tax base of the MNE, we have to specify which factor cost is tax-deductible. In accordance with most real world tax systems, we assume that payroll is fully deductible. In contrast, capital cost may be partially deductible since the governments may grant partial depreciation allowances only and/or allows the MNE to deduct the cost of debt finance but not the cost of equity finance. We denote the fraction of capital cost that is deductible by the parameter $\rho \in[0,1]$. The tax base of the MNE in country $i$ is then given by

$$
\Phi^{i}=F\left(k_{i}, \ell_{i}\right)-\rho r k_{i}-w_{i} \ell_{i}+s_{i}
$$

The tax base of the MNE in country $i$ equals sales (output) adjusted by the deductible capital and labor cost and by profit shifting from or to country $i$.

The decisive difference of our model to previous studies on the comparison between Separate Accounting and Formula Apportionment is that we consider a general equilibrium model. In our framework, not only the local wage rates are endogenously determined, but also is the world interest rate. Formally, the wage rate in country $i$ follows from the local labor market equilibrium condition

$$
\ell_{i}=\bar{\ell}
$$

which equates labor demand $\ell_{i}$ and labor endowment $\bar{\ell}$ that is inelastically supplied. Labor demand depends on the wage rates according to the MNE's profit maximization which is considered below. The world interest rate is determined on the world capital market which clears according to the condition

$$
\sum_{j} k_{j}=n \bar{k}
$$

\footnotetext{
${ }^{1}$ Most of our results are not affected if a transaction is associated with cost in one subsidiary only.
} 
Equation (4) requires that world capital demand has to equal world capital supply, where each country is assumed to have capital endowment $\bar{k}$ which it inelastically supplies at the world capital market. Capital demand depends on the interest rate due to the MNE's profit maximization considered in the next sections. Previous studies partially consider the labor market (3), but our approach is the first that takes into account an endogenous world interest rate determined on the world capital market (4).

\section{Separate Accounting}

Profit Maximization and Markets. Under Separate Accounting corporate income is taxed in the country where the MNE it declares. Denoting by $t_{j}$ country $j$ 's statutory tax rate, the MNE's total after-tax profit can be written as

$$
\Pi=\sum_{j}\left(1-t_{j}\right) \Phi^{j}-r(1-\rho) \sum_{j} k_{j}-\sum_{j} C\left(s_{j}\right)
$$

The MNE chooses investment, labor input and profit shifting in order to maximize after-tax profit (5) subject to the constraint (1) and the tax base definition (2). In doing so, it takes as given the tax rates and the factor prices. Denoting by $\lambda$ the Lagrange multiplier associated with (1), the first-order conditions of profit maximization read

$$
\begin{aligned}
\left(1-t_{i}\right)\left[F_{k}\left(k_{i}, \ell_{i}\right)-\rho r\right]-r(1-\rho) & =0, \\
F_{\ell}\left(k_{i}, \ell_{i}\right)-w_{i} & =0, \\
\left(1-t_{i}\right)-C^{\prime}\left(s_{i}\right)+\lambda & =0 .
\end{aligned}
$$

These conditions have the usual interpretation. Equation (6) and (7) equate the (netof-tax) marginal return to capital and labor to the respective (deductible) factor cost. Equation (8) states that the MNE shifts profit up to the point where the marginal concealment cost equals the marginal shifting benefit. This condition implies that shifting to country $i$ will be larger than shifting to country $j$ if country $i$ has the lower tax rate, i.e. $t_{i}<t_{j}$ implies $C^{\prime}\left(s_{i}\right)>C^{\prime}\left(s_{j}\right)$ and $s_{i}>s_{j}$ due to $C^{\prime \prime}(\cdot)>0$. Together with (1) it follows that there is profit shifting from high-tax to low-tax countries as long as non-zero tax rate differentials between countries exist.

Below we will analyze the tax competition game between the $n$ countries. To that end we need the comparative static effects of tax rate changes on the MNE's investment, labor demand and profit shifting decision. We follow previous studies and restrict attention to symmetric equilibria with $t_{i}=t$. Equations (1) - (4) and (6) - (8) 
then imply $k_{i}=\bar{k}, \ell_{i}=\bar{\ell}, w_{i}=w, \Phi^{i}=\Phi$ and $s_{i}=0$. Totally differentiating $(1)-(4)$ and (6) - (8) and then applying the symmetry assumption, Appendix A shows

$$
\begin{aligned}
\frac{\partial r}{\partial t_{i}} & =-\frac{F_{k}-\rho r}{n(1-\rho t)}<0, & & \\
\frac{\partial k_{i}}{\partial t_{i}} & =\frac{(n-1)\left(F_{k}-\rho r\right)}{n(1-t) F_{k k}}<0, & & \frac{\partial k_{i}}{\partial t_{j}}=-\frac{F_{k}-\rho r}{n(1-t) F_{k k}}>0 \\
\frac{\partial w_{i}}{\partial t_{i}} & =\frac{(n-1)\left(F_{k}-\rho r\right) F_{\ell k}}{n(1-t) F_{k k}}<0, & & \frac{\partial w_{i}}{\partial t_{j}}=-\frac{\left(F_{k}-\rho r\right) F_{\ell k}}{n(1-t) F_{k k}}>0 \\
\frac{\partial s_{i}}{\partial t_{i}} & =-\frac{n-1}{n C^{\prime \prime}}<0, & & \frac{\partial s_{i}}{\partial t_{j}}=\frac{1}{n C^{\prime \prime}}>0
\end{aligned}
$$

where $i \neq j$. These expressions have a straightforward interpretation. A unilateral increase in one country's tax rate causes a rise in the tax burden in this country and, thus, induces the MNE to reduce capital demand and the tax base in this country. As consequence, the equilibrium world interest rate falls and investment in all other countries goes up. Hence, the MNE reallocates capital from the tax-increasing country to all other countries as formally shown by (9) and (10). Since labor is complementary to capital $\left(F_{\ell k}>0\right)$, decreases in capital call for a reduction in labor demand so that the input factor labor becomes more abundant and the wage rate decreases. Thus, the wage rate shrinks in the tax-increasing country but rises elsewhere as follows from (11). Finally, (12) shows that if a country raises its tax rate, profit shifting to this country declines whereas profit shifting to other countries increases.

Tax competition. We now turn to the tax competition game under Separate Accounting. It is assumed that the governments of the countries behave non-cooperatively, using tax rates as their strategic variables. We consider the case where each country's government chooses its corporate tax rate in order to maximize tax revenue. This assumption reflects the idea of Leviathan governments which is often seen quite relevant, in particular in the context of corporate taxation (e.g. Wilson 1999), and therefore has frequently been used by previous studies on Separate Accounting versus Formula Apportionment (e.g. Nielsen et al., 2006, and Pethig and Wagener, 2008).

Under the tax principle of Separate Accounting, a country's tax revenue equals its tax rate times the tax base. For country $i$ we obtain

$$
g_{i}=t_{i} \Phi^{i}
$$

Country $i$ maximizes (13) with respect to its tax rate $t_{i}$ taken as given the tax rates of the other countries. In doing so, it takes into account equations $(9)-(12)$, i.e. the 
impact of its tax policy on the MNE's behavior and on the local labor market as well as on the world capital market. The latter effect is the main difference of our analysis to previous studies: In our model, each country is aware of its impact on the capital market and the equilibrium interest rate. Only if the number of countries becomes large and, thus, each country becomes small, the effect of the individual country on the world interest rate vanishes. Formally, this follows from (9) and $n \rightarrow \infty$. As we will see below, however, even such an extreme case is different from assuming a fixed $r$, as done in previous studies, since the interest rate in our model is then still endogenous and varies with aggregate policy changes.

The first-order condition of country $i$ 's tax revenue maximization is $\partial g_{i} / \partial t_{i}=0$. It determines country $i$ 's reaction function, i.e. its best response to the other countries' tax rates. Solving the first-order conditions of all $n$ countries gives the equilibrium tax rates of the tax competition game. As already mentioned above, we follow previous studies and focus on a symmetric equilibrium with tax rates $t_{i}=\tilde{t}$. Our main interest is to assess the efficiency properties of $\tilde{t}$. This can be done by investigating the fiscal externality which is represented by the effect of country $i$ 's tax rate on all other countries' tax revenues, i.e. $\sum_{j \neq i} \partial g_{j} / \partial t_{i}$. Starting from a symmetric equilibrium, the fiscal externality reflects the tax revenue effect of a coordinated tax rate increase. A positive (negative) sign of the fiscal externality shows that tax coordination leads to an increase (decrease) of tax revenue in each country and, thus, to a Pareto improvement (deterioration) so that the equilibrium tax rate $\tilde{t}$ is inefficiently low (high). In order to determine the sign of the fiscal externality, we differentiate (13) and take into account (2), (9) - (12) and the symmetry property. This yields

$$
\sum_{j \neq i} \frac{\partial g_{j}}{\partial t_{i}}=(n-1) \frac{\partial g_{j}}{\partial t_{i}}=\tilde{t}(n-1) \frac{\partial \Phi^{j}}{\partial t_{i}}=(n-1) \mathrm{PE}+\left.(n-1) \mathrm{TE}\right|_{\mathrm{SA}}
$$

where

$$
\begin{aligned}
\mathrm{PE} & =\tilde{t} \frac{\partial s_{j}}{\partial t_{i}}=\frac{\tilde{t}}{n C^{\prime \prime}}>0 \\
\left.\mathrm{TE}\right|_{\mathrm{SA}} & =\tilde{t}\left[\left(F_{k}-\rho r\right) \frac{\partial k_{j}}{\partial t_{i}}-\rho \bar{k} \frac{\partial r}{\partial t_{i}}-\bar{\ell} \frac{\partial w_{j}}{\partial t_{i}}\right] \\
& =-\frac{\tilde{t}\left(F_{k}-\rho r\right)}{n(1-\tilde{t})(1-\rho \tilde{t}) F_{k k}}\left[(1-\rho \tilde{t})\left(F_{k}-\rho r-\bar{\ell} F_{\ell k}\right)-(1-\tilde{t}) \rho \bar{k} F_{k k}\right]
\end{aligned}
$$

According to $(14)-(16)$, the total cross country effect of country $i$ 's tax rate on tax revenue in country $j \neq i$ can be decomposed into two sub-externalities. The first is the profit shifting externality $\mathrm{PE}$ in (15). If country $i$ increases its tax rate $t_{i}$, the MNE 
shifts more profit to country $j$ which enhances country $j$ 's tax base and tax revenue. The profit shifting externality is positive and tends to inefficient undertaxation. The second externality is the tax base externality $\left.\mathrm{TE}\right|_{\mathrm{SA}}$ in (16). This externality is constituted by three effects that build on each other. First, increasing $t_{i}$ lowers the MNE's capital demand $k_{i}$ in country $i$. As consequence, world capital demand and, thus, the price of capital represented by the interest rate $r$ decrease. This has a positive effect on the tax base in country $j$ as the MNE's capital cost in country $j$ becomes lower. Second, the reduction in the interest rate $r$ induces the MNE to increase investment $k_{j}$ in country $j .^{2}$ Hence, also this second effect raises the tax base in country $j$. Third, the increase in investment $k_{j}$ induces the MNE to demand more labor in country $j$ since capital and labor are complements. The wage rate $w_{j}$ in country $j$ therefore goes up with a raise in payroll and a drop in the tax base in country $j$ as an end result.

Since the third effect goes into the opposite direction of the first and second effect, the sign of the tax base externality is ambiguous. To illustrate this point, consider the special case of no deductibility of capital cost $(\rho=0)$ and a CES production function $F(k, \ell)=\left[\delta k^{\nu}+(1-\delta) \ell^{\nu}\right]^{\frac{\mu}{\nu}}$ with $\left.\delta \in\right] 0,1[, \mu \in] 0,1[$ and $\nu \leq 1$. Note that for the CES function the substitution elasticity $\eta:=1 /(1-\nu)$ is positive correlated with the parameter $\nu$. For notational convenience, we define $K:=\delta \bar{k}^{\nu}, L=(1-\delta) \bar{\ell}^{\nu}$ and $Z:=K+L$. We can then write $F=Z^{\frac{\mu}{\nu}}, F_{k}=\mu K Z^{\frac{\mu}{\nu}-1} / \bar{k}, F_{\ell}=\mu L Z^{\frac{\mu}{\nu}-1} / \bar{\ell}$, $F_{k k}=-\mu[(1-\mu) K+(1-\nu) L] K Z^{\frac{\mu}{\nu}-2} / \bar{k}^{2}$ and $F_{\ell k}=\mu(\mu-\nu) K L Z^{\frac{\mu}{\nu}-2} / \bar{k} \bar{\ell}$. Inserting this and $\rho=0$ into $(16)$ and defining $\Psi:=\tilde{t} \mu K Z^{\frac{\mu}{\nu}-1} /[n(1-\tilde{t})]>0$ yields

$$
\left.\mathrm{TE}\right|_{\mathrm{SA}}=\Psi \frac{K+(1-\mu+\nu) L}{(1-\mu) K+(1-\nu) L} .
$$

From (17) we infer that the tax base externality is positive as long as $\nu \geq 0$ or, equivalently, $\eta \geq 1$. For $\nu=0$ this parameter range covers as a special case the CobbDouglas production function. However, if the parameter $\nu$ is sufficiently negative, then the tax base externality may become negative as well. This is intuitively plausible since for a very small $\nu$ and, thus, a very small substitution elasticity $\eta$, capital and labor are strong complements. In such a case, the above mentioned third effect of country $i$ 's tax rate on country $j$ 's tax base via the rise in the wage rate is quite large because the increase in investment in country $j$ induces the MNE to increase labor demand in country $j$ a lot. Hence, the third effect may overcompensate the other two effects and, thus, may render the tax base externality negative pointing to overtaxation.

\footnotetext{
${ }^{2}$ The fall in $r$ exerts also a positive effect on investment $k_{i}$ in the tax-increasing country $i$. But this effect is more than compensated by the initial drop in $k_{i}$.
} 
The possibly different signs of the profit shifting and tax base externalities prove

Proposition 1. Suppose the tax competition game under Separate Accounting attains a symmetric Nash equilibrium with $t_{i}=\tilde{t}$. Then the equilibrium corporate tax rate $\tilde{t}$ may be inefficiently low or high.

It is important to compare this insight with the result obtained by previous studies referred to in the Introduction. Previous authors came to the conclusion that under Separate Accounting tax revenue maximizing governments set their corporate tax rates inefficiently low. The reason for the difference to our result in Proposition 1 is that previous studies proceed on the assumption of a fixed interest rate. If $r$ is exogenously given, none of the above mentioned three effects of country i's tax rate on country $j$ 's tax base is present since the decline of the MNE's investment in country $i$ is then followed neither by a fall in the interest rate nor by an increase in investment and the wage rate in country $j$. Hence, with a fixed interest rate there is no tax base externality, and the remaining profit shifting externality results in inefficient undertaxation. As our proposition shows, however, this may no longer be true, if we explicitly consider the world capital market that endogenously determines the interest rate.

One may conjecture that this difference to previous studies is due to an implicit assumption that each country is sufficiently large in order to take into account its effect on the world interest rate. But the following proposition (proven in Appendix B) shows that our result prevails if $n$ grows without bounds so that each country becomes infinitesimally small and no longer has an effect on the interest rate.

Proposition 2. Suppose the tax competition game under Separate Accounting attains a symmetric Nash equilibrium with $t_{i}=\tilde{t}$. Then Proposition 1 is true also for small countries $(n \rightarrow \infty)$. Moreover, we obtain

$$
\operatorname{sign}\left\{\frac{\mathrm{d} \tilde{t}}{\mathrm{~d} n}\right\}=-\operatorname{sign}\left\{\mathrm{PE}+\left.\mathrm{TE}\right|_{\mathrm{SA}}\right\} .
$$

It is true that for an infinite number of countries the impact of country $i$ 's tax rate on the interest rate and, thus, on investment and wages in an individual country $j \neq i$ converges to zero. Formally, TE $\left.\right|_{\mathrm{SA}}$ in (16) vanishes if $n \rightarrow \infty$. However, if the number of countries grows without bounds, the effect of country $i$ 's tax rate on the aggregate number of countries is still non-zero. This follows from (14) where TE $\left.\right|_{\mathrm{SA}}$ is multiplied by $n-1$ which represents the number of competitors of country $i$. Put differently, the tax base externality inflicted by country $i$ 's tax rate on a single competitor becomes 
infinitesimally small when the number of countries becomes larger and larger, but the tax base externality inflicted on the aggregate number of competitors is still there and ambiguous in sign. This is the reason why Proposition 1 is also true for small countries. Consistently with this argument, the second part of Proposition 2 shows that the deviation of the equilibrium tax rate from its efficient level becomes larger if the number of countries increases. This is true independent of whether we have inefficient undertaxation $\left(\mathrm{PE}+\left.\mathrm{TE}\right|_{\mathrm{SA}}>0\right)$ or overtaxation $\left(\mathrm{PE}+\left.\mathrm{TE}\right|_{\mathrm{SA}}<0\right)$.

It may finally be worthwhile to compare our results under Separate Accounting to the insights of the (capital) tax competition literature already referred to in the Introduction. This literature identifies the so-called capital flight externality that reflects the increase in country $j$ 's investment upon an increase in country $i$ 's tax rate. It is positive and unambiguously points to inefficiently low tax rates. This effect is similar to the comparative static effect in (10). As shown by Proposition 1 and 2, however, in our framework countries may end up with inefficient overtaxation. The reason for this difference is that we model corporate taxation as a tax on taxable income whereas the (capital) tax competition literature uses the short cut of a (unit) wealth tax on capital, i.e. tax payments there amounts to $t_{i} k_{i}$. Hence, in the previous literature there is no cross country effect on tax bases working through an increase in wages. This effect is the driving force behind possible overtaxation in our framework.

\section{Formula Apportionment}

Profit Maximization and Markets. We now turn to the principle of Formula Apportionment. Under this taxation principle, the tax bases of the MNE's subsidiaries are first consolidated and then apportionment to the taxing countries according to a certain formula. We consider a formula that contains all three apportionment factors usually employed in practice. More specifically, the part of the MNE's consolidated tax base assigned to country $i$ is proportional to the MNE's capital share $k_{i} / \sum_{j} k_{j}$, sales share $F\left(k_{i}\right) / \sum_{j} F\left(k_{j}\right)$ and payroll share $w_{i} \ell_{i} / \sum_{j} w_{j} \ell_{j}$. Denoting by $\gamma, \sigma$ and $\varphi$ the formula weights of these apportionment factors, the share of the consolidated tax base assigned to country $i$ reads

$$
A^{i}\left(k_{i}, k_{-i}, \ell_{i}, \ell_{-i}, w_{i}, w_{-i}\right)=\gamma \frac{k_{i}}{\sum_{j} k_{j}}+\sigma \frac{F\left(k_{i}, \ell_{i}\right)}{\sum_{j} F\left(k_{j}, \ell_{j}\right)}+\varphi \frac{w_{i} \ell_{i}}{\sum_{j} w_{j} \ell_{j}},
$$

where $x_{-i}:=\left(x_{1}, \ldots, x_{i-1}, x_{i+1}, \ldots, x_{n}\right)$ for $x=k, \ell, w$, and where $(\gamma, \sigma, \varphi) \in\{(\gamma, \sigma, \varphi) \mid$ $(\gamma, \sigma, \varphi) \in[0,1]^{3}$ and $\left.\gamma+\sigma+\varphi=1\right\}$. 
The MNE's tax burden in country $i$ is given by $t_{i} A^{i}(\cdot) \sum_{j} \Phi^{j}$. The MNE's total after-tax profit under Formula Apportionment can be written as

$$
\Pi=(1-\tau) \sum_{j} \Phi^{j}-r(1-\rho) \sum_{j} k_{j}-\sum_{j} C\left(s_{j}\right),
$$

where

$$
\tau=t_{i} A^{i}+\sum_{j \neq i} t_{j} A^{j}=t_{i}+\sum_{j \neq i}\left(t_{j}-t_{i}\right) A^{j}
$$

is the effective tax rate of the MNE. Note that in equation (20) we used the property $\sum_{j} A^{j}=1$. The objective of the MNE is to maximize the after-tax profit (19) with respect to capital, labor and profit shifting taking into account (2), (20) and $\sum_{j} s_{j}=0$. Because tax bases are consolidated, the MNE is not able to reduce its tax liability by profit shifting. It therefore chooses profit shifting such that the concealment cost is minimized, i.e. $s_{i}=0$ for all $i$. The MNE's optimal capital and labor demand, respectively, is characterized by the first-order conditions

$$
\begin{aligned}
\sum_{j} \Phi^{j} \cdot \sum_{j \neq i}\left(t_{i}-t_{j}\right) A_{k_{i}}^{j}+(1-\tau)\left[F_{k}\left(k_{i}, \ell_{i}\right)-\rho r\right]-r(1-\rho) & =0, \\
\sum_{j} \Phi^{j} \cdot \sum_{j \neq i}\left(t_{i}-t_{j}\right) A_{\ell_{i}}^{j}+(1-\tau)\left[F_{\ell}\left(k_{i}, \ell_{i}\right)-w_{i}\right] & =0 .
\end{aligned}
$$

There are two differences of these first-order conditions to the respective first-order conditions (6) and (7) under Separate Accounting. First, under Formula Apportionment the net-of-tax marginal returns to the input factors are computed with the effective tax rate $\tau$ instead of the national tax rates $t_{i}$. The reason is consolidation of tax bases. Second, due to the apportionment mechanism the MNE has ceteris paribus an incentive to invest more and demand more labor in countries with below-average tax burden than in countries with above-average tax burden. The reason is that, by doing so, the MNE increases the share of the consolidated tax base assigned to low-tax countries and reduces the share of the consolidated tax base assigned to high-tax countries so that its total tax burden falls. This formula manipulation incentive of the MNE is reflected by the first term on the LHS of (21) and (22), respectively.

Equations (21) and (22) together with the market clearing conditions (3) and (4) determine the MNE's decision and the factor prices as functions of the corporate tax rates. We again need the comparative static effects of tax rate changes on the economy's equilibrium and restrict our attention to symmetric Nash equilibria with equal tax 
rates $t_{i}=\tau=t$. It then follows $k_{i}=\bar{k}, \ell_{i}=\bar{\ell}, w_{i}=w$ and $\Phi^{i}=\Phi$. Moreover, the apportionment formula satisfies $A^{j}=1 / n, A_{k_{i}}^{j}=-A_{k_{i}}^{i} /(n-1)=-\left(\gamma / k+\sigma F_{k} / F\right) / n^{2}$, $A_{\ell_{i}}^{j}=-A_{\ell_{i}}^{i} /(n-1)=-\left(\sigma F_{\ell} / F+\varphi / \ell\right) / n^{2}$ and $A_{w_{i}}^{j}=-A_{w_{i}}^{i} /(n-1)=-\varphi /\left(n^{2} w\right)$. The comparative static analysis, which is delegated to Appendix C, yields

$$
\begin{array}{r}
\frac{\partial r}{\partial t_{i}}=-\frac{F_{k}-\rho r}{n(1-t \rho)}<0, \\
\frac{\partial k_{i}}{\partial t_{i}}=\frac{(n-1) \Phi}{n(1-t) F_{k k}}\left(\frac{\gamma}{k}+\frac{\sigma F_{k}}{F}\right)<0, \quad \frac{\partial k_{i}}{\partial t_{j}}=-\frac{\Phi}{n(1-t) F_{k k}}\left(\frac{\gamma}{k}+\frac{\sigma F_{k}}{F}\right)>0 \\
\frac{\partial w_{i}}{\partial t_{i}}=\frac{(n-1) \Phi}{n(1-t) F_{k k}}\left[\frac{\gamma F_{\ell k}}{k}+\frac{\sigma\left(F_{\ell k} F_{k}-F_{\ell} F_{k k}\right)}{F}-\frac{\varphi F_{k k}}{\ell}\right]<0, \\
\frac{\partial w_{i}}{\partial t_{j}}=-\frac{\Phi}{n(1-t) F_{k k}}\left[\frac{\gamma F_{\ell k}}{k}+\frac{\sigma\left(F_{\ell k} F_{k}-F_{\ell} F_{k k}\right)}{F}-\frac{\varphi F_{k k}}{\ell}\right]>0,
\end{array}
$$

for $i \neq j$. The comparative static effects $(23)-(26)$ have the same signs as the corresponding effects (9) - (11) under Separate Accounting. However, the intuition is different. Under Separate Accounting, the MNE reduces investment in a tax-increasing country since this lowers the tax base in this country. Such an effect is not present under Formula Apportionment since taxes fall on the consolidated tax base, so the MNE is not able to reduce the tax base by reallocating capital between countries. But under Formula Apportionment the MNE reduces capital demand in a tax-increasing country since it faces the above mentioned formula manipulation incentive. It reallocates capital from a tax-increasing country to the other countries since this raises the share of the consolidated tax base assigned to the other countries. The increase in investment in the other countries is brought about by a reduction in the world interest rate. Formally, these effects are captured by (23) and (24). Moreover, the complementarity between labor and capital implies that labor demand and wages move into the same direction as investment. This effect is amplified by the formula manipulation incentive that holds also with respect to labor and wages. ${ }^{3}$ Overall, (25) and (26) show that wages in the tax-increasing country go down while they increase in all other countries.

Tax competition. Under Formula Apportionment tax revenue of a country equals the share of the MNE's consolidated tax base assigned to this country multiplied by

\footnotetext{
${ }^{3}$ Strictly speaking, the formula manipulation incentive holds with respect to labor and wages only if the formula contains the sales and/or payroll factors. It holds with respect to investment only if the formula contains the property and/or sales factors. But in any case, the formula manipulation incentive will be present at least with respect to one of the input factors.
} 
the national corporate tax rate. For country $i$ we obtain

$$
g_{i}=t_{i} A^{i}\left(k_{i}, k_{-i}, \ell_{i}, \ell_{-i}, w_{i}, w_{-i}\right) \sum_{j} \Phi^{j}
$$

Country $i$ maximizes (27) with respect to $t_{i}$ taking as given $t_{j}$ for all $j \neq i$. It takes into account the impact of its policy choice on the MNE's behavior and the factor markets. This impact is represented by $(23)-(26)$. The Nash equilibrium of the tax competition game is constituted by $\partial g_{i} / \partial t_{i}=0$ for all $i$. The focus is again on a symmetric equilibrium with $t_{i}=\hat{t}$. In order to evaluate the efficiency properties of the equilibrium tax rate, we compute in Appendix D the cross derivative of (27) as

$$
\sum_{j \neq i} \frac{\partial g_{j}}{\partial t_{i}}=(n-1) \frac{\partial g_{j}}{\partial t_{i}}=(n-1)\left(\left.\mathrm{TE}\right|_{\mathrm{FA}}+\left.\mathrm{FE}\right|_{(\gamma, \sigma, \varphi)}\right)
$$

where

$$
\begin{aligned}
\left.\mathrm{TE}\right|_{\mathrm{FA}}=\hat{t} A \frac{\partial \sum_{j} \Phi^{j}}{\partial t_{i}}=-\hat{t} \rho \bar{k} \frac{\partial r}{\partial t_{i}}=\hat{t} \rho \bar{k} \frac{F_{k}-\rho r}{n(1-\hat{t} \rho)}>0 \\
\left.\mathrm{FE}\right|_{(\gamma, \sigma, \varphi)=\hat{t} n \Phi \frac{\partial A^{j}}{\partial t_{i}}=\hat{t} \Phi}\left[\left(\frac{\gamma}{\bar{k}}+\frac{\sigma F_{k}}{F}\right) \frac{\partial k_{j}}{\partial t_{i}}+\frac{\varphi}{w} \frac{\partial w_{j}}{\partial t_{i}}\right] \\
=-\frac{\hat{t} \Phi^{2}}{n(1-\hat{t}) F_{k k}}\left[\left(\frac{\gamma}{\bar{k}}+\frac{\sigma F_{k}}{F}\right)^{2}\right. \\
\left.+\frac{\varphi}{F_{\ell}}\left(\frac{\gamma F_{\ell k}}{\bar{k}}+\frac{\sigma\left(F_{\ell k} F_{k}-F_{\ell} F_{k k}\right)}{F}-\frac{\varphi F_{k k}}{\bar{\ell}}\right)\right]>0 .
\end{aligned}
$$

According to $(28)$ - (30), the cross country effect of tax rates under Formula Apportionment can be decomposed into two sub-externalities. The first is the tax base externality $\left.\mathrm{TE}\right|_{\mathrm{FA}}$ given by (29). The reason for this externality is that an increase in one country's tax rate reduces capital demand in this country and, thus, the world interest rate. As consequence, the MNE's capital cost falls so that the consolidated tax base and tax revenue in all countries go up. The tax base externality is always positive. Remember that under Formula Apportionment reallocating input factors has no effect on the consolidated tax base and, hence, does not influence the tax base externality. However, reallocation has an effect on the apportionment of the consolidated tax base. If one country increases its tax rate, the MNE shifts capital and labor from this country to all other countries since it faces the formula manipulation incentive. This raises the share of the consolidated tax base assigned to the other countries and causes the formula externality $\left.\mathrm{FE}\right|_{(\gamma, \sigma, \varphi)}$ defined in (30). The formula externality is positive, too. 
Since both externalities under Formula Apportionment are positive, we obtain

Proposition 3. Suppose the tax competition game under Formula Apportionment attains a symmetric Nash equilibrium with $t_{i}=\hat{t}$. Then the equilibrium corporate tax rate $\hat{t}$ is inefficiently low.

It is again interesting to compare this insight with the result of previous studies referred to in the Introduction. Previous authors also derive the formula externality which is exactly the same as the externality in (30). In contrast, previous studies identify a tax base externality that is different from that in (29). When the interest rate is fixed, an increase in one country's tax rate reduces capital and labor demand in this country, but leaves unaltered the interest rate and factor demand in all other countries. ${ }^{4}$ Hence, there is no direct effect on the consolidated tax base and the other countries' tax revenue via a decline in the interest rate. In addition, the effects on the consolidated tax base caused by changes in investment and wages do not cancel out. Only investment and wages in the tax-increasing country are varied, so the consolidated tax base and tax revenue of the other countries are now affected by these changes. As consequence, the tax base externality may be positive or negative, depending on whether the negative effect of the decline in investment or the positive effect of the fall in wages dominates. With a fixed interest rate, it is therefore not clear whether tax competition leads to inefficiently low or high corporate tax rates. In contrast, our Proposition 3 shows that with an endogenous interest rate corporate taxes under Formula Apportionment are inefficiently low since the tax base externality is unambiguously positive.

As for the case of Separate Accounting, we can again show that this conclusion prevails if the countries become infinitesimally small. By virtually the same proof as that of Proposition 2, we obtain

Proposition 4. Suppose the tax competition game under Formula Apportionment attains a symmetric Nash equilibrium with $t_{i}=\hat{t}$. Then Proposition 3 is true also for small countries $(n \rightarrow \infty)$. Moreover, we obtain

$$
\operatorname{sign}\left\{\frac{\mathrm{d} \hat{t}}{\mathrm{~d} n}\right\}=-\operatorname{sign}\left\{\left.\mathrm{TE}\right|_{\mathrm{FA}}+\left.\mathrm{FE}\right|_{(\gamma, \sigma, \varphi)}\right\}<0 .
$$

When the number of countries becomes very large, the cross country effect of tax rates between two countries converges to zero. However, the aggregate effect of one

\footnotetext{
${ }^{4}$ This argument abstracts from the changes in factor inputs caused by the formula manipulation incentive since these changes are already reflected in the formula externality
} 
country's tax rate on all other countries is still positive. This is the reason why we obtain inefficient undertaxation under Formula Apportionment even if countries are small. Moreover, if the number of countries grows, more and more countries compete for mobile capital. As shown by the second part of Proposition 4, it follows that the equilibrium corporate tax rate under Formula Apportionment is decreasing in the number of countries. Inefficient undertaxation is therefore more pronounced when there are many countries than when only a few countries compete for mobile input factors.

The extent of the inefficiency under Formula Apportionment depends not only on the number of countries, but also on the shape of the formula. We therefore now turn to the comparison of different formulas. Remember that TE $\left.\right|_{\mathrm{FA}}$ is independent of the formula weights $(\gamma, \sigma, \varphi)$, so we need to focus on the formula externality (30) only. Defining $\Upsilon:=-\hat{t} \Phi^{2} /\left[n(1-\hat{t}) F_{k k}\right]>0$ and considering the extreme cases of the formula weights, the formula externality can be written as

$$
\left.\mathrm{FE}\right|_{(1,0,0)}=\Upsilon \frac{1}{\bar{k}^{2}},\left.\quad \mathrm{FE}\right|_{(0,1,0)}=\Upsilon \frac{F_{k}^{2}}{F^{2}},\left.\quad \mathrm{FE}\right|_{(0,0,1)}=-\Upsilon \frac{F_{k k}}{\bar{\ell} F_{\ell}} .
$$

Concavity of the production function implies $F>\bar{k} F_{k}$ so that $\left.\mathrm{FE}\right|_{(1,0,0)}>\left.\mathrm{FE}\right|_{(0,1,0)}$. The other comparisons are not unique, in general. However, for the CES production function introduced above we obtain $F_{k}^{2} / F^{2}=\mu^{2} K^{2} /\left[\bar{k}^{2}(K+L)^{2}\right]$ and $-F_{k k} /\left(\bar{\ell} F_{\ell}\right)=$ $[(1-\mu) K+(1-\nu) L] K /\left[\bar{k}^{2} L(K+L)\right]$. These expressions allow the following statement.

Proposition 5. Suppose the tax competition game under Formula Apportionment attains a symmetric Nash equilibrium with $t_{i}=\hat{t}$. Then

(i) the tax rate under the pure sales formula $(\gamma, \sigma, \varphi)=(0,1,0)$ is greater than the tax rate under the pure capital formula $(\gamma, \sigma, \varphi)=(1,0,0)$.

If additionally the production function is of the CES type $F(k, \ell)=\left[\delta k^{\nu}+(1-\delta) \ell^{\nu}\right]^{\frac{\mu}{\nu}}$ with $\delta \in] 0,1[, \mu \in] 0,1[$ and $\nu \leq 1$, then

(ii) the tax rate under the pure sales formula $(\gamma, \sigma, \varphi)=(0,1,0)$ is greater than the tax rate under the pure payroll formula $(\gamma, \sigma, \varphi)=(0,0,1)$ if $\nu \leq 2-\mu-\mu^{2}$.

The first part of Proposition 5 implies that inefficient undertaxation is less severe if the formula uses the sales factor instead of the property factor. The reason for this result is that we assume decreasing returns to scale caused by a third fixed production factor. Hence, the MNE's formula manipulation incentive and the associated formula externality are larger under the property formula than under the sales formula. Under the property formula, apportionment is targeted directly at the production factors 
whereas under the sales formula the MNE's manipulation effort is hampered by the third production factor which cannot be altered by the MNE. Whether the sales formula is also superior to the payroll formula, however, depends not only on the importance of the fixed production factor but also on the elasticity of substitution between capital and labor. Intuitively, apportionment is directed at the production factor also under the payroll formula. But this factor cannot as easily manipulated as the capital factor because labor is immobile. Hence, the conditions rendering the sales formula superior to the payroll formula are stronger than those rendering the sales formula superior to the property formula. More specific, capital and labor have to be sufficiently strong complements in the sense that $\nu \leq 2-\mu-\mu^{2}$.

\section{Concluding Remarks}

In this paper, we have investigated the efficiency properties of corporate income taxation under Separate Accounting and Formula Apportionment. In contrast to the previous literature, our analysis takes explicitly into account the world capital market and the world interest rate determined on this market. Such a change in assumptions turned out to reverse the results obtained in the previous literature. With a fixed interest rate, Separate Accounting leads to corporate tax rates that are always inefficiently low, while under Formula Apportionment countries may end up with inefficient overtaxation. In the presence of an endogenous world interest rate, in contrast, it is the other way round. Under Separate Accounting we obtain an ambiguous result whereas Formula Apportionment leads to inefficiently low tax rates. This conclusion is true independent of whether countries are large or small.

Our results may have important policy implications. For the Formula Apportionment systems in countries like Germany and Switzerland, one may argue that the fixed interest rate assumption is suitable since these countries usually take as given the world interest rate and it also cannot be expected that corporate income taxation in these countries has a significant impact on the world capital market. This is different, however, for the U.S. which is usually seen the largest player in global trade of capital. Hence, even if the U.S. states do not take into account the effects of their Formula Apportionment taxation on the world interest rate, such an effect will be present and important for evaluating the efficiency of corporate taxation. Perhaps even more important, the endogenous interest rate assumption is relevant for the current reform discussion in the European Union. The European Union, too, is large enough to in- 
fluence the world capital market, even if the individual member countries ignore this effect. Therefore, the switch from Separate Accounting to Formula Apportionment may miss the indented aim of mitigating detrimental tax competition. Such a situation would occur if the present tax rates are close to their efficient levels because the profit shifting and tax base externalties neutralize each other. ${ }^{5}$ Then a switch to Formula Apportionment would be welfare-reducing since it unambiguously reduces the corporate tax rates below their efficient levels.

\section{Appendix}

A. Derivation of (9) - (12). Equations (1) - (4) and (6) - (8) determine $r, k_{i}, \ell_{i}$ and $w_{i}$ for all $i$. Inserting (3) into the other equations and differentiating (6) yields

$$
(1-t) F_{k k} \mathrm{~d} k_{i}=(1-\rho t) \mathrm{d} r+\left(F_{k}-\rho r\right) \mathrm{d} t_{i}
$$

Inserting (A1) in $\sum_{i} \mathrm{~d} k_{i}=0$ from (4) and solving for $\mathrm{d} r$ gives

$$
\mathrm{d} r=-\frac{F_{k}-\rho r}{n(1-\rho t)} \sum_{i} \mathrm{~d} t_{i} .
$$

Setting all but one $\mathrm{d} t_{i}$ equal to zero then proves $\partial r / \partial t_{i}$ in (9). Using this result in (A1) shows (10). From (7) we get $\mathrm{d} w_{i}=F_{\ell k} \mathrm{~d} k_{i}$. Using (10) proves (11). In order to show (12), totally differentiate (8). This yields

$$
C^{\prime \prime} \mathrm{d} s_{i}=\mathrm{d} \lambda-\mathrm{d} t_{i}
$$

Inserting (A3) in $\sum_{i} \mathrm{~d} s_{i}=0$ from (1) and rearranging terms gives $n \mathrm{~d} \lambda=\sum_{i} \mathrm{~d} t_{i}$. If we set all but one $\mathrm{d} t_{i}$ equal to zero, it follows $\partial \lambda / \partial t_{i}=1 / n$. From (A3), we obtain (12).

B. Proof of Proposition 2. In a symmetric equilibrium, equation (6) reads

$$
(1-\tilde{t})\left[F_{k}(\bar{k}, \bar{\ell})-\rho r\right]-r(1-\rho)=0
$$

It determines the equilibrium interest rate $r$ as a function of $\tilde{t}$. Note that (A4) does not contain $n$, so $r$ does not depend directly on the number of countries $n$. For a given

\footnotetext{
${ }^{5}$ There are a lot of empirical studies showing that corporate tax rates in Europe have declined over the last decades and that there are strategic interactions between the policies of European countries, e.g. Devereux et al. $(2002,2008)$. But note that these studies do not explicitly quantify fiscal externalities and therefore do not allow for judging whether tax rates are inefficiently low or high.
} 
$\tilde{t}$, equations (15) and (16) then imply

$$
\begin{aligned}
\lim _{n \rightarrow \infty}(n-1) \mathrm{PE} & =\frac{\tilde{t}}{C^{\prime \prime}}>0, \\
\left.\lim _{n \rightarrow \infty}(n-1) \mathrm{TE}\right|_{\mathrm{SA}} & =-\frac{\tilde{t}\left(F_{k}-\rho r\right)\left[(1-\rho \tilde{t})\left(F_{k}-\rho r-\bar{\ell} F_{\ell k}\right)-(1-\tilde{t}) \rho \bar{k} F_{k k}\right]}{(1-\tilde{t})(1-\rho \tilde{t}) F_{k k}} \gtreqless 0 .
\end{aligned}
$$

This proves the first part of Proposition 2.

In order to show the second part, note that in a symmetric equilibrium the firstorder condition of country $i$ 's revenue maximization can be written as $G^{i}\left(t_{1}, \ldots, t_{n}, n\right):=$ $\partial g_{i} / \partial t_{i}=0$ with $t_{1}=\ldots=t_{n}=\tilde{t}$. Total differentiation yields

$$
\frac{\mathrm{d} \tilde{t}}{\mathrm{~d} n}=-\frac{G_{n}^{i}}{\sum_{j} G_{t_{j}}^{i}} .
$$

Due to symmetry, we can write $\sum_{j} G_{t_{j}}^{i}=G_{t_{i}}^{i}+(n-1) G_{t_{j}}^{i}$ where in the latter term we have $j \neq i$. The sign of this expression can be determined by the stability of the tax competition game: Stability requires that the Jacobian matrix of the system $G^{i}\left(t_{1}, \ldots, t_{n}, n\right)=0$ for $i=1, \ldots, n$ is negative semi-definite. Computing the Jacobian matrix and its determinant and then applying the symmetry property yields $\left(G_{t_{i}}^{i}-\right.$ $\left.G_{t_{j}}^{i}\right)^{n-1}\left[G_{t_{i}}^{i}+(n-1) G_{t_{j}}^{i}\right]$. This expression has to be positive if $n$ is even and negative if $n$ is odd. It follows $G_{t_{i}}^{i}+(n-1) G_{t_{j}}^{i}<0$ where we have used $G_{t_{i}}^{i}<0$ due to the secondorder condition of country $i$ 's tax revenue maximization. Hence, the denominator of (A5) is negative and the overall sign of $\mathrm{d} \tilde{t} / \mathrm{d} n$ depends on the sign of $G_{n}^{i}$. To determine this sign, we explicitly compute $G^{i}\left(t_{1}, \ldots, t_{n}, n\right)=\partial g_{i} / \partial t_{i}=0$ and apply the symmetry property. Using $(6)-(8)$ and $(9)-(12)$ yields after some tedious calculations $G^{i}(\tilde{t}, \ldots, \tilde{t}, n)=F(\bar{k}, \bar{\ell})-\bar{\ell} F_{\ell}(\bar{k}, \bar{\ell})-\rho r \bar{k}+\tilde{t} \rho \bar{k} \frac{F_{k}-\rho r}{1-\rho \tilde{t}}-(n-1)\left(\mathrm{PE}+\left.\mathrm{TE}\right|_{\mathrm{SA}}\right)=0$.

The first four terms of this expression do not depend on $n$ as we argued above that $r$ does not directly depend on $n$. Note also that we can keep $\tilde{t}$ constant since we are looking for the partial derivative of $G^{i}(\cdot)$ with respect to $n$. Using (15) and (16) it follows $G_{n}^{i}=-\left(\mathrm{PE}+\left.\mathrm{TE}\right|_{\mathrm{SA}}\right) / n$ which inserted into (A5) completes the proof.

C. Derivation of (23) - (26). Totally differentiating (3) yields $\mathrm{d} \ell_{i}=0$. Inserting this observation together with (22) in the total differential of (4), (21) and (22) and then applying the symmetry property yields

$$
n \Phi \sum_{j \neq i}\left(\mathrm{~d} t_{i}-\mathrm{d} t_{j}\right) A_{k_{i}}^{j}+(1-t) F_{k k} \mathrm{~d} k_{i}-\left(F_{k}-\rho r\right) \mathrm{d} \tau-(1-t \rho) \mathrm{d} r=0,
$$




$$
\begin{array}{r}
n \Phi \sum_{j \neq i}\left(\mathrm{~d} t_{i}-\mathrm{d} t_{j}\right) A_{\ell_{i}}^{j}+(1-t) F_{\ell k} \mathrm{~d} k_{i}-(1-t) \mathrm{d} w_{i}=0 \\
\sum_{j} \mathrm{~d} k_{j}=0 .
\end{array}
$$

From equation (20) and the symmetry assumption we obtain

$$
\mathrm{d} \tau=\mathrm{d} t_{i}+\sum_{j \neq i}\left(\mathrm{~d} t_{j}-\mathrm{d} t_{i}\right) A^{j}=\sum_{j} \frac{\mathrm{d} t_{j}}{n} .
$$

Next, rearrange (A6) to

$$
\mathrm{d} k_{i}=\frac{1}{(1-t) F_{k k}}\left\{\frac{F_{k}-\rho r}{n} \sum_{j} \mathrm{~d} t_{j}-n \Phi A_{k_{i}}^{j}\left[(n-1) \mathrm{d} t_{i}-\sum_{j \neq i} \mathrm{~d} t_{j}\right]+(1-t \rho) \mathrm{d} r\right\}(\mathrm{A}
$$

Note that

$$
\sum_{i}\left[(n-1) \mathrm{d} t_{i}-\sum_{j \neq i} \mathrm{~d} t_{j}\right]=0
$$

Inserting (A10) into (A8), taking into account (A11) and solving for $\mathrm{d} r$ yields

$$
\mathrm{d} r=-\frac{F_{k}-\rho r}{n(1-t \rho)} \sum_{j} \mathrm{~d} t_{j}
$$

If we set one $\mathrm{d} t_{j} \neq 0$ and all others equal to zero, we obtain equation (23). Next, equations (23) and (A10) immediately imply

$$
\frac{\partial k_{i}}{\partial t_{i}}=-\frac{n(n-1) \Phi A_{k_{i}}^{j}}{(1-t) F_{k k}}, \quad \frac{\partial k_{i}}{\partial t_{j}}=\frac{n \Phi A_{k_{i}}^{j}}{(1-t) F_{k k}}
$$

Using the expression for $A_{k_{i}}^{j}$ in (A13) proves (24). Finally, we rearrange (A7) to

$$
\mathrm{d} w_{i}=F_{\ell k} \mathrm{~d} k_{i}+\frac{n \Phi}{1-t} \sum_{j \neq i}\left(\mathrm{~d} t_{i}-\mathrm{d} t_{j}\right) A_{\ell_{i}}^{j}
$$

which establishes

$$
\frac{\partial w_{i}}{\partial t_{i}}=F_{\ell k} \frac{\partial k_{i}}{\partial t_{i}}+\frac{n(n-1) \Phi}{1-t} A_{\ell_{i}}^{j}, \quad \frac{\partial w_{i}}{\partial t_{j}}=F_{\ell k} \frac{\partial k_{i}}{\partial t_{j}}-\frac{n \Phi}{1-t} A_{\ell_{i}}^{j} .
$$

If we use equation (24) and the expression for $A_{\ell_{i}}^{j}$ in (A15), we obtain after some rearrangements equations (25) and (26). 
D. Derivation of $(\mathbf{2 8})-(\mathbf{3 0})$. From the definition of $\Phi^{j}$ in $(2)$ we obtain

$$
\left.\mathrm{TE}\right|_{\mathrm{FA}}=\hat{t} A \frac{\partial \sum_{j} \Phi^{j}}{\partial t_{i}}=\frac{\hat{t}}{n}\left\{\left(F_{k}-\rho r\right) \sum_{j} \frac{\partial k_{j}}{\partial t_{i}}-\bar{\ell} \sum_{j} \frac{\partial w_{j}}{\partial t_{i}}-n \rho \bar{k} \frac{\partial r}{\partial t_{i}}\right\} .
$$

Equations $(24)-(26)$ imply $\sum_{j}\left(\partial k_{j} / \partial t_{i}\right)=\sum_{j}\left(\partial w_{j} / \partial t_{i}\right)=0$. Inserting these expressions into (A16) and taking into account (23) proves (29). In order to prove (30), we differentiate $A^{j}$ from (18) to obtain

$$
\begin{aligned}
\left.\mathrm{FE}\right|_{(\gamma, \sigma, \varphi)}=\hat{t} n \Phi \frac{\partial A^{j}}{\partial t_{i}}=\hat{t} n \Phi\left[A_{k_{j}}^{j} \frac{\partial k_{j}}{\partial t_{i}}+A_{k_{i}}^{j} \frac{\partial k_{i}}{\partial t_{i}}+(n-2) A_{k_{h}}^{j} \frac{\partial k_{h}}{\partial t_{i}}\right. \\
\left.A_{w_{j}}^{j} \frac{\partial w_{j}}{\partial t_{i}}+A_{w_{i}}^{j} \frac{\partial w_{i}}{\partial t_{i}}+(n-2) A_{w_{h}}^{j} \frac{\partial w_{h}}{\partial t_{i}}\right](\mathrm{A} 17)
\end{aligned}
$$

where $i \neq j \neq h \neq i$. In a symmetric equilibrium, we have $\partial k_{h} / \partial t_{i}=\partial k_{j} / \partial t_{i}$, $\partial w_{h} / \partial t_{i}=\partial w_{j} / \partial t_{i}, \partial k_{i} / \partial t_{i}=-(n-1) \partial k_{j} / \partial t_{i}$ and $\partial w_{i} / \partial t_{i}=-(n-1) \partial w_{j} / \partial t_{i}$. Inserting this into (A17) and taking into account $A_{k_{h}}^{j}=A_{k_{i}}^{j}$ and $A_{w_{h}}^{j}=A_{w_{i}}^{j}$ gives

$$
\left.\mathrm{FE}\right|_{(\gamma, \sigma, \varphi)}=\hat{t n} \phi\left[\frac{\partial k_{j}}{\partial t_{i}}\left(A_{k_{j}}^{j}-A_{k_{i}}^{j}\right)+\frac{\partial w_{j}}{\partial t_{i}}\left(A_{w_{j}}^{j}-A_{w_{i}}^{j}\right)\right] .
$$

In the symmetric equilibrium, we get $A_{k_{j}}^{j}-A_{k_{i}}^{j}=-(n-1) A_{k_{i}}^{j}-A_{k_{i}}^{j}=-n A_{k_{i}}^{j}=$ $\left(\gamma \bar{k}+\sigma F_{k} / F\right) / n$ and $A_{w_{j}}^{j}-A_{w_{i}}^{j}=-(n-1) A_{w_{i}}^{j}-A_{w_{i}}^{j}=-n A_{w_{i}}^{j}=\varphi /(n w)$. Making use of these derivatives, (24) and (26) in (A18) proves (30).

\section{References}

Combrugghe, A. and H. Tulkens (1990), 'On Pareto Improving Tax Changes under Fiscal Competition', Journal of Public Economics 41, 335-50.

Devereux, M., Griffith, R. and A. Klemm (2002), Corporate Income Tax Reforms and International Tax Competition, Economic Policy 35, 451-95.

Devereux, M., Lockwood, B. and M. Redoano (2008), Do Countries Compete over Corporate Tax Rates?, Journal of Public Economics, forthcoming.

Eggert, W. and G. Schjelderup (2003), 'Symmetric Tax Competition under Formula Apportionment', Journal of Public Economic Theory 5, 439-46.

Eichner, T. and M. Runkel (2008), Why the European Union Should Adopt Formula Apportionment with a Sales Factor, Scandinavian Journal of Economics, forthcoming. 
European Commission (2001), 'Towards an Internal Market Without Tax Obstacles: A Strategy for Providing Companies with a Consolidated Corporate Tax Base for Their EU-Wide Activities', $\operatorname{COM}(2001)$, 582 final (October 23).

Gordon, R.H. and J.D. Wilson (1986), 'An Examination of Multijurisdictional Corporate Income Taxation under Formula Apportionment', Econometrica 54, 1357-73.

Haufler, A. and G. Schjelderup (2000), 'Corporate Tax Systems and Cross Country Profit Shifting', Oxford Economic Papers 52, 306-25.

Hoyt, W.H. (1991), 'Optimal Taxation, Nash Equilibrium, and Market Power', Journal of Urban Economics 30, 123-31.

Kant, C. (1988), 'Endogenous Transfer Pricing and the Effects of Uncertain Regulation', Journal of International Economics 24, 147-57.

McLure, C.E. (1980), 'The State Corporate Income Tax: Lambs in Wolves' Clothing', in: Aaron, A.J. and M.J. Boskin (Eds.), The Economics of Taxation, Washington DC: The Brookings Institution, 327-36.

Mintz, J. and M. Smart (2004), 'Income Shifting, Investment, and Tax Competition: Theory and Evidence from Provincial Taxation in Canada', Journal of Public Economics 88, 1149-1168.

Nielsen, S.B., Raimondos-Møller, P. and G. Schjelderup (2003), 'Formula Apportionment and Transfer Pricing under Oligopolistic Competition', Journal of Public Economic Theory 5, 419-37.

Nielsen, S.B., Raimondos-Møller, P. and G. Schjelderup (2006), 'Company Taxation and Tax Spillovers: Separate Accounting versus Formula Apportionment', mimeo.

Pethig, R. and A. Wagener (2008), 'Profit Tax Competition and Formula Apportionment', International Tax and Public Finance, forthcoming.

Pinto, S.M. (2007), 'Corporate Profit Tax, Capital Mobility, and Formula Apportionment', Journal of Urban Economics 62, 76-102.

Riedel, N. and M. Runkel (2007), 'Company Tax Reform with a Water's Edge', Journal of Public Economics 91, 1533-54.

Sørensen, P.B. (2004), 'Company Tax Reform in the European Union', International Tax and Public Finance 11, 91-115. 
Wellisch, D. (2004), 'Taxation under Formula Apportionment - Tax Competition, Tax Incidence, and the Choice of Apportionment Factors', Finanzarchiv 60, 24-41.

Wilson, J. (1985), 'Optimal Property Taxation in the Presence of Interregional Capital Mobility', Journal of Urban Economics 18, 73-89.

Wilson, J. (1986), 'A Theory of Inter-regional Tax Competition', Journal of Urban Economics 19, 295-315.

Wilson, J.D. (1999), 'Theories of Tax Competition', National Tax Journal 52, 269-304.

Zodrow, G.R. and P.M. Mieszkowski (1986), 'Pigou, Property Taxation and the Underprovision of Local Public Goods, Journal of Urban Economics 19, 356-70. 


\section{CESifo Working Paper Series}

for full list see www.cesifo-group.org/wp

(address: Poschingerstr. 5, 81679 Munich, Germany, office@cesifo.de)

2257 C.A.E. Goodhart, The Regulatory Response to the Financial Crisis, March 2008

2258 Stefan Bauernschuster, Oliver Falck and Stephan Heblich, The Impact of Continuous Training on a Firm's Innovations, March 2008

2259 Michael Grimm and Stephan Klasen, Geography vs. Institutions at the Village Level, March 2008

2260 Fwu-Ranq Chang, Property Insurance, Portfolio Selection and their Interdependence, March 2008

2261 J. Atsu Amegashie and Marco Runkel, The Paradoxes of Revenge in Conflicts, March 2008

2262 Hans Jarle Kind, Marko Koethenbuerger and Guttorm Schjelderup, Efficiency Enhancing Taxation in Two-sided Markets, March 2008

2263 M. Hashem Pesaran, Til Schuermann and L. Vanessa Smith, Forecasting Economic and Financial Variables with Global VARs, March 2008

2264 Volker Grossmann, Entrepreneurial Innovation and Sustained Long-run Growth without Weak or Strong Scale Effects, March 2008

2265 Robert S. Chirinko and Huntley Schaller, The Irreversibility Premium, March 2008

2266 Andrea Galeotti and José Luis Moraga-González, Platform Intermediation in a Market for Differentiated Products, April 2008

2267 Torben M. Andersen and Michael Svarer, The Role of Workfare in Striking a Balance between Incentives and Insurance in the Labour Market, April 2008

2268 Harald Badinger, Cyclical Fiscal Policy, Output Volatility, and Economic Growth, April 2008

2269 Thomas Aronsson and Erkki Koskela, Outsourcing and Optimal Nonlinear Taxation: A Note, April 2008

2270 Gary E. Bolton, Claudia Loebbecke and Axel Ockenfels, How Social Reputation Networks Interact with Competition in Anonymous Online Trading: An Experimental Study, April 2008

2271 Nikolaus Wolf, Scylla and Charybdis. Explaining Europe’s Exit from Gold, January 1928 - December 1936, April 2008 
2272 Michael Funke and Marc Gronwald, The Undisclosed Renminbi Basket: Are the Markets Telling us something about where the Renminbi - US Dollar Exchange Rate is Going?, April 2008

2273 Thor Olav Thoresen and Annette Alstadsæter, Shifts in Organizational Form under a Dual Income Tax System, April 2008

2274 Helge Berger and Volker Nitsch, Too many Cooks? Committees in Monetary Policy, April 2008

2275 Yin-Wong Cheung and Eiji Fujii, Deviations from the Law of One Price in Japan, April 2008

2276 Michael S. Michael, Sajal Lahiri and Panos Hatzipanayotou, Integrated Reforms of Indirect Taxes in the Presence of Pollution, April 2008

2277 Bas Jacobs, Is Prescott Right? Welfare State Policies and the Incentives to Work, Learn and Retire, April 2008

2278 Burkhard Heer and Alfred Maußner, Value Function Iteration as a Solution Method for the Ramsey Model, April 2008

2279 Jarko Fidrmuc and Christa Hainz, Integrating with their Feet: Cross-Border Lending at the German-Austrian Border, April 2008

2280 Kristof Dascher and Alexander Haupt, The Political Economy of Regional Integration Projects at Borders where Rich and Poor Meet: The Role of Cross-Border Shopping and Community Sorting, April 2008

2281 Katrin Assenmacher-Wesche and M. Hashem Pesaran, A VECX* Model of the Swiss Economy, April 2008

2282 Christophe Rault, Robert Sova and Ana Maria Sova, Modeling International Trade Flows between CEEC and OECD Countries, April 2008

2283 Timo Boppart, Josef Falkinger, Volker Grossmann, Ulrich Woitek and Gabriela Wüthrich, Qualifying Religion: The Role of Plural Identities for Educational Production, April 2008

2284 Armin Falk, David Huffman and W. Bentley MacLeod, Institutions and Contract Enforcement, April 2008

2285 Axel Dreher and Stefan Voigt, Does Membership in International Organizations Increase Governments' Credibility? Testing the Effects of Delegating Powers, April 2008

2286 Xavier Freixas and Bruno M. Parigi, Lender of Last Resort and Bank Closure Policy, April 2008 
2287 Regina Dionisius, Samuel Muehlemann, Harald Pfeifer, Günter Walden, Felix Wenzelmann and Stefan C. Wolter, Cost and Benefit of Apprenticeship Training - A Comparison of Germany and Switzerland, April 2008

2288 Francesco Daveri and Cecilia Jona-Lasinio, Off-Shoring and Productivity Growth in the Italian Manufacturing Industries, April 2008

2289 Mikael Priks, Do Surveillance Cameras Affect Unruly Behavior? A Close Look at Grandstands, April 2008

2290 Marianna Belloc and Daniela Federici, A Two-Country NATREX Model for the Euro/Dollar, April 2008

2291 Nicolas Treich, The Value of a Statistical Life under Ambiguity Aversion, April 2008

2292 J. Atsu Amegashie, Socially-Tolerable Discrimination, April 2008

2293 M. Hashem Pesaran and Andreas Pick, Forecasting Random Walks Under Drift Instability, April 2008

2294 Steven Brakman, Gus Garita, Harry Garretsen and Charles van Marrewijk, Unlocking the Value of Cross-Border Mergers and Acquisitions, May 2008

2295 Eric O’N. Fisher and Kathryn G. Marshall, The Structure of the American Economy, May 2008

2296 Claudia M. Buch and Martin Schlotter, Regional Origins of Employment Volatility: Evidence from German States, May 2008

2297 Helmuth Cremer, Philippe De Donder, Dario Maldonado and Pierre Pestieau, Taxing Sin Goods and Subsidizing Health Care, May 2008

2298 Reinhilde Veugelers and Frederick van der Ploeg, Reforming European Universities: Scope for an Evidence-Based Process, May 2008

2299 Jon H. Fiva and Lars J. Kirkebøen, Does the Housing Market React to New Information on School Quality?, May 2008

2300 Tina Klautke and Alfons J. Weichenrieder, Interest Income Tax Evasion, the EU Savings Directive, and Capital Market Effects, May 2008

2301 Harald Badinger and Peter Egger, GM Estimation of Higher Order Spatial Autoregressive Processes in Panel Data Error Component Models, May 2008

2302 Jan K. Brueckner, Slot-Based Approaches to Airport Congestion Management, May 2008

2303 Sören Blomquist, Vidar Christiansen and Luca Micheletto, Public Provision of Private Goods and Nondistortionary Marginal Tax Rates, May 2008 
2304 Dan Anderberg and Alessandro Balestrino, The Political Economy of Post-Compulsory Education Policy with Endogenous Credit Constraints, May 2008

2305 Tomer Blumkin, Yoram Margalioth and Efraim Sadka, The Role of Stigma in the Design of Welfare Programs, May 2008

2306 Vesa Kanniainen and Paolo M. Panteghini, Tax Neutrality: Illusion or Reality? The Case of Entrepreneurship, May 2008

2307 Thomas Dohmen, Armin Falk, David Huffman and Uwe Sunde, The Intergenerational Transmission of Risk and Trust Attitudes, May 2008

2308 Guglielmo Maria Caporale and Mario Cerrato, Using Chebyshev Polynomials to Approximate Partial Differential Equations, May 2008

2309 Peter Egger and Doina Maria Radulescu, Labour Taxation and Foreign Direct Investment, May 2008

2310 Laurent Linnemer, Dissipative Advertising Signals Quality even without Repeat Purchases, May 2008

2311 Jordi Jofre-Monseny and Albert Solé-Ollé, Which Communities should be afraid of Mobility? The Effects of Agglomeration Economies on the Sensitivity of Firm Location to Local Taxes, May 2008

2312 Andreas Haufler and Ferdinand Mittermaier, Unionisation Triggers Tax Incentives to Attract Foreign Direct Investment, May 2008

2313 Ronel Elul and Piero Gottardi, Bankruptcy: Is it enough to Forgive or must we also Forget?, May 2008

2314 Andreas Irmen and Johanna Kuehnel, Productive Government Expenditure and Economic Growth, May 2008

2315 Beate Henschel, Carsten Pohl and Marcel Thum, Demographic Change and Regional Labour Markets: The Case of Eastern Germany, May 2008

2316 Gabriel Felbermayr, Wido Geis and Wilhelm Kohler, Restrictive Immigration Policy in Germany: Pains and Gains Foregone?, May 2008

2317 Michael Hofmann, Gerhard Kempkes and Helmut Seitz, Demographic Change and Public Sector Budgets in a Federal System, May 2008

2318 Paul De Grauwe, Macroeconomic Modeling when Agents are Imperfectly Informed, June 2008

2319 Johann K. Brunner and Susanne Pech, Optimum Taxation of Inheritances, June 2008

2320 Thomas Eichner and Marco Runkel, Corporate Income Taxation of Multinationals in a General Equilibrium Model, June 2008 